\title{
The Roles of Abu Bakar Sidiq in Maintaining Lampung Residence During the Dutch Military Aggression II in North Lampung
}

\author{
Myristica Imanita \\ History Education \\ Lampung University \\ Lampung, Indonesia \\ myristica.imanita@fkip.unila.ac.id
}

\author{
Marzius Insani \\ History Education \\ Lampung University \\ Lampung, Indonesia \\ marzius.insani@fkip.unila.ac.id
}

\begin{abstract}
The Dutch managed to enter Lampung through the Port of Panjang on January 1st, 1949, which was the gateway to the southern tip of Sumatra and the territory of ARLI. The Dutch were able to easily control this territory because of their unbalanced strength and weaponry. The increasingly chaotic situation in Lampung caused the Lampung Residency to move from Talang Padang to Way Tenong and ended up in Bukit Kemuning, North Lampung. Abu Bakar Sidiq's struggle to keep Lampung as part of the independent Republic of Indonesia was not easy. However, the struggle of Abu Bakar Sidiq and his troops was not fully recorded as part of the legacy of the local history of Lampung, which caused the role of Abu Bakar Sidiq as a regional hero not known by the people of Lampung even in his birthplace, Bukit Kemuning, North Lampung. The objectives of this research were (1) providing information about the biography and finding out the track record of Abu Bakar Sidiq's struggle in Lampung; also (2) revealing the role of Abu Bakar Sidiq in defending Lampung Residency during the Dutch Military Aggression II in North Lampung. This research was qualitative research with historical methods and data collection techniques used library techniques, documentation, and interview with Abu Bakar Sidiq descendants. The results of this research indicated that Abu Bakar Sidiq was originally a TKR (People's Security Army) commander with the rank of First Lieutenant in the Bukit Kemuning sub-district, North Lampung. Then, he served as commander of the Indonesian Special Police Force, chief of Marine Police staff, and lastly served as chairman of the Association of Indonesian Navy Base IA of Lampung Province. In addition, Abu Bakar Sidiq and his troops helped defend Indonesia's independence in Lampung by guerrillas throughout the Lampung area, which was under attack from the Dutch. In the Dutch Aggression I and II, the Lampung government center (residence of Lampung) moved around until the Bukit Kemuning of North Lampung. Abu Bakar Sidiq placed his troops on guard on every road to Bukit Kemuning to keep the Lampung residency safe, intending to repel the enemy. In addition, Abu Bakar Sidiq recruited youths from Bukit Kemuning
\end{abstract}

to become volunteer emergency troops (paramilitary troops) to increase strength and provide military training.

Keywords-Abu Bakar Sidiq, Biography, Defending Lampung Residency.

\section{INTRODUCTION}

The Indonesian nation has gone through a long historical journey with difficult struggles to escape from the power of foreign nations. The Indonesian people experienced pressure and misery caused by the policies made by the colonialists. The proclamation of Indonesia's independence on August 17th, 1945, was a critical moment or event for the Indonesian nation. Although Indonesia has succeeded in proclaiming independence, the struggle has not been over yet.

The Dutch tried to regain control of Indonesia by making various diplomatic efforts but the Indonesian side firmly rejected these efforts [1]. The diplomatic efforts offered by the Dutch only provided benefits for the Netherlands itself so that it always experienced failures. Despite having experienced failures, the Dutch desire to dominate Indonesia did not stop. The Dutch troops tried to infiltrate NICA to research the situation and infiltrate their troops into Indonesian areas considered strategic, such as mining areas, port cities, and plantation areas.

The Dutch military aggression that was carried out relentlessly had caused reactions from the International Community and several UN member countries asking for action until resolution NO. 27 was issued on August 1 st, 1947, which contained a call for a ceasefire and a peaceful settlement of the conflict between the Netherlands and Indonesia [2].

The signing of the Renville Agreement resulted from the resolution that was signed on January 17th, 1948. However, this agreement could not work as 
expected because the Dutch denied the agreement. After all, Indonesia was not serious about implementing the contents of the agreement. For that reason, the Netherlands relaunched its military attack to remove The Indonesian state off the map and arrested all civilian and military figures because the Dutch considered them extremists [3]. On December 19th, 1948, the Dutch Army launched military aggression II.

The struggle for independence emerged throughout Indonesia, including in Lampung. The Lampung regional government center or known as the Lampung residency is part of the development of government administration which later became Sumatra Province with ten residencies, namely: Aceh Residency, East Sumatra Residency, Tapanuli Residency, West Sumatra Residency, Riau Residency, Jambi Residency, Bengkulu Residency, Lampung Residency, and Bangka-Belitung Residency.

The very cunning Dutch used the ceasefire to strengthen themselves to destroy the Republic of Indonesia. There was no goodwill in diplomacy and negotiations.

On December 19th, 1949, the Dutch army launched its second aggression. The Dutch tried to occupy areas of the Republic of Indonesia, and cities considered strategic to expand their power to re-colonize the Indonesian people. Battles to defend Indonesia's independence appeared everywhere in various remote areas of the country and in the Lampung area, which also received threats and attacks by the Dutch military.

On January 1st, 1949, the Dutch managed to enter Lampung Residency through the Port of Panjang, which was the gateway at the tip of Southern Sumatra, which was the territory of ARLI. The Dutch could easily control this territory because of their unbalanced strength and weaponry.

At that moment, the ALRI troops gathered in the Tataan Building, which was designated as an emergency headquarters, and immediately consolidated the troops by splitting the troops into two:

- ALRI main force led by captain C. Souhoka on the south front.

- The car squad led by First Lieutenant Abu Bakar Sidiq

was on duty in North Lampung.

Furthermore, the Dutch attacked and succeeded in occupying Teluk Betung, which was the capital of the Lampung Residency. The Lampung resident had to leave the Pringsewu area, and the Deputy Resident had to stay in Tanjungkarang to run the temporary government. However, the vice-resident, R.A Basjid, instead fled to Menggala through Kasui. As a result, Raden Rukandi as the resident of Lampung was arrested by the Dutch and declared by the Dutch that Lampung was wholly owned by the Dutch (research and development of Lampung cultural values, history of the Lampung area). The increasingly difficult situation did not dampen the spirit of the Lampung fighters. Party leaders and military leaders in Lampung immediately appointed Mr. Gele Harun as Lampung Resident.

When the situation in Lampung became increasingly pressing, the residency of Lampung moved from Talang Padang to Way Tenong. It ended up in Bukit Kemuning, North Lampung because it was part of the Lampung region that the Dutch had not successfully controlled. The Dutch did not easily occupy Bukit Kemuning, North Lampung Regency. Abu Bakar Sidiq had made a defense by assigning part of his troops and conducting emergency military training and war strategy training for the Bukit Kemuning residents.

Ironically, the struggle of Abu Bakar Sidiq as a regional fighter/ hero who has contributed to maintaining Lampung to remain a part of the independent Republic of Indonesia was not fully recorded as part of the legacy of Lampung's local history. As a result, Abu Bakar Sidiq as a regional hero was not known by the Lampung people, even in his birthplace, namely Bukit Kemuning, North Lampung.

Very few references or even almost non-existent documents make researchers look for traces to get more data by visiting the Abu Bakar Sidiq residence in Bukit Kemuning, North Lampung, followed by the hideout headquarters Ulak Rengas Village, North Lampung Regency.

Researchers conducted interviews with descendants of Abu Bakar Sidiq, and researchers obtained documents or personal records of Abu Bakar Sidiq.

Based on the research background above, the authors were interested in examining the role of $\mathrm{Abu}$ Bakar Sidiq in Defending the Lampung Residency during the Dutch Military Aggression II in North Lampung.

\section{LITERATURE REVIEW}

\section{A. Role Concept}

"Role is a dynamic process of position or status if a person carries out his rights and obligations according to his position, he carries out a role" [4]. "Role is a behavior expected by others from someone who occupies a certain status, a role that can be learned as part of the individual" [5]. "Role is an action taken by a person or group of people in an event" [6]. In the W.J.S Poerwadarminta opinion, "a role is something that is part of or holds the leadership especially in the occurrence of an event" [6].

Cohen states that "carrying out the roles expected by society in a way that suits them. This kind of situation is called a Prescribed role but sometimes the expected person does not behave in ways that are 
consistent with the expectations of others. They can still be considered to be carrying out the role given by the community even though it is not consistent with the expectations of the role giver. The enacted role is the actual state of a person in carrying out a certain role" [5].

Based on experts' opinion above, the role is an action taken by a person to carry out his rights and obligations according to his position in an event he is experiencing. According to his position, a person who carries out his rights and obligations has carried out his role.

\section{B. The Concept of Maintaining Lampung Residency}

According to WJS. Poerdarminto, maintaining is trying to keep it or leave it in its original state. Meanwhile, "A residency was an administrative division within a province in the Dutch East Indies (Indonesia) until the 1950s. A residency (regentschappen) consists of several feelings (districts). Not all provinces in Indonesia have ever had a residency. A residency has only existed on Java, Sumatra, Kalimantan, Bali, Lombok, and Sulawesi islands, or usually in the areas with a large population." (Wikipedia, Indonesia).

"The Lampung Residency has existed since the Japanese colonial era in 1943. By the Supreme Commander of the Twenty-fifth Army, a civilian government was formed on the island of Sumatra, which divided the Sumatra island into 9 (nine) Residencies (syu), namely East Sumatra, Tapanuli, West Sumatra, Riau, Jambi, Bengkahulu, Palembang, Lampung, and Bangka-Biliton.'

"The regencies in the Lampung Residency area were as follows [7]:

1) North Lampung Regency

- Menggala Kawedanan

- Kotabumi Kawedanan

- Way Kanan Kawedanan

- Krui Kawedanan

2) Central Lampung Regency

- Sukadana Kawedanan

- Metro Kawedanan

- Way Seputih Kawedanan

3) South Lampung Regency

- Kalianda Kawedanan

- Telukbetung Kawedanan

- Kedondong Kawedanan

- Gedongtatan Kawedanan

Based on the information above, the Lampung Residency has initially been part of the Sumatra
Province. Each province was divided into several residencies, then the residencies were in charge of the regencies, beneath them were the municipalities, and after that, beneath them were the kawedanans. In conclusion, maintaining the residence of Lampung can be interpreted as an effort to keep the regional government center safe and able to carry out its functions.

\section{The Concept of Dutch Military Aggression II}

Etymologically, the Dutch Military Aggression II, also known as Operation Crow (Dutch: Operatie Kraai), occurred on December 19th, 1948, which began with an attack on Yogyakarta, the capital city of Indonesia at that time, and the arrest of Soekarno, Moh. Hatta, Sjahrir, and several other Indonesian figures.

The Dutch tried to regain control of Indonesia by crippling the capital city, which was in Yogyakarta at that time, to destroy the defenses of the extremists (according to the Dutch version), erasing Indonesia from the map and establishing the United States of Indonesia, which was bound in one union with the Kingdom of the Netherlands.

The Dutch made a surprise attack so that the Dutch could easily control Yogyakarta. However, his action managed to attract international attention and draw criticism [3]; therefore, in the end, negotiations took place between the Republicans and the Netherlands under the supervision of KTN (Komisi Tiga Negara), which carried a mandate from the United Nations so that a follow-up to the implementation of the Renville was signed a few months earlier.

However, despite receiving criticism from the international community, the Dutch's determination to dominate the Republic of Indonesia never subsided. The Dutch were looking for unreasonable excuses so that it seemed as the Indonesians did not comply with the Renville agreement contents so that the agreement could not be continued. Finally, the Dutch could again carry out their military attack.

The Dutch then began to expand their military offensive to potential areas of Indonesia. One of them was Lampung. The area with abundant natural resources did not escape the Dutch military aggression II, which first stopped through Port of Panjang and controlled Teluk Betung.

Based on the description above, it can be concluded that the Dutch Military Aggression II was aggression carried out at the end of the month in 1948 as follow-up aggression aimed at destroying the Indonesian republic and making Indonesia an Indonesian state under the Kingdom's rule of the Netherlands.

\section{RESEARCH METHODS}

This research was descriptive research using the historical method. Notosusanto explains that the historical method is [8]: 
"a set of systematic principles or rules intended to provide practical assistance in the effort to collect materials for history, evaluate critically, and then present a synthesis of the results in written form.

Furthermore, Notosusanto divides historical research into four steps, namely:

- Heuristics, namely the process of searching, finding, and collecting traces of the past.

- Criticism, which is to investigate whether the traces are genuine or not

- Interpretation, which is to determine the meaning that is most related to the facts obtained.

- Historiography, namely conveying the synthesis obtained in the form of stories.

This study's data collection techniques were library techniques, interview techniques, and documentation techniques, while the data analysis technique used was qualitative data analysis techniques.

\section{RESULT AND DISCUSSION}

\section{A. Biography of Abu Bakar Sidiq}

Abu Bakar Sidiq was born in Ulak Rengas Village, Bukit Kemuning District, North Lampung on January 10th, 1921. Abu Bakar Sidiq received his education at HIS (Hollandsch - Inlandsche School) then continued his education at Net Natsionaal Handles Collegium of Bandung. Abu Bakar Sidiq previously served as Head of the Indonesian Republic Veterans Legion (LVRI) Branch Headquarter II of North Lampung and Chairman of the Association of Ex-Members of the Navy Base 1A Lampung.

When the Republic of Indonesia proclaimed independence on August 17th, 1945, Abu Bakar Sidiq was serving as FUKU MARGACHO (PEMBARAP/village headman) Rebang Seputih clan or currently known as Bukit District Kemuning, North Lampung. Bukit Kemuning was occupied by a company of Japanese troops (Butai Seribu) at that time.

During the formation of the TKR in Bukit Kemuning, Abu Bakar Sidiq was appointed Commander of the TKR with the rank of Lieutenant I for the Bukit Kemuning District sector. In detail, 1 section consisted of (60) members of ex-HEIHO, GIUGUN, and LECHT BESCHERMING DIENTS (LBD) youths.

There was a rebellion in Kotabumi by the Goloks led by the former police detective Rasuddin. As a result of the rebellion, all TKR in North Lampung were ordered to gather in Tanjung Karang.

Arriving Abu Bakar Sidiq in Tanjung Karang by Resident Mr. Abaas and Komissaris Sutan Rosman ordered Abu Bakar Sidiq to form a detachment (Kompi) of the Special Barisan Police based in Gedong Air, Tanjung Karang.

TABLE I. THE COMPOSITION OF THE SPECIAL BARISAN STAFF

\begin{tabular}{|l|l|}
\hline \multicolumn{1}{|c|}{ Commander } & \multicolumn{1}{c|}{ Abu Bakar Sidiq } \\
\hline Head of Staff & Sersan Mayor Bahrun \\
\hline Military Trainer & Sersan Mayor A.Mukti \\
\hline Examiner Section & Sersan Mayor Zainuddin \\
\hline Intel Section & Sersan Mayor A. Muhi \\
\hline Equipment Section & Sersan Mayor A.Marzuki Rachman \\
\hline
\end{tabular}

Besides, Abu Bakar Sidiq was once assigned to the police center at the Tanjung Karang office, where he became the Head of the Lampung Regional Police. Then, Abu Bakar Sidiq left the police and moved to the Lampung Navy Base IA.

The composition of the Navy and PTL (Army Police) at that time:

- Commander of ALRI IA Lampung: Major M. M. Haidar

- Deputy Commander: Captain C. Sohoka

- Battalion Commander: Captain K.L. Tobing

- Commander of PTL: II Marine Lieutenant Wahab Ismail

- Deputy Commander: Marine Lieutenant III. Abu Bakar Sidiq

- Police Chief: Sergeant Major Endar Harun

- Commander of Kota Agung Post: Sergeant Major Adhars

- Commander of Kalianda Post: Sergeant Abdul Mukti

- Commander of the Panjang Post: Sergeant Major Endar Harun

At that time, the primary step taken by the PTL was to equip the weaponry because the Dutch warship movement that was often pacing back and forth in the bay of Lampung was already visible.

\section{B. The Struggle of Abu Bakar Sidiq}

On July 21st, 1947, the Netherlands began carrying out its first aggression. Palembang was attacked so that there was a war of 5 days or five nights. The Palembang Marine Commander, Major Sarongsong, asked the Lampung IA Base to send assistance. Then, Abu Bakar Sidiq was ordered by the IA Lampung commander to go to Martapura with 30 troops to join Ismail Susin's battalion. In this battle, the Navy IA Base IA Lampung lost one member.

Then, the Dutch troops moved to Lengkayap, and the Navy troops headed to the location to provide 
assistance to join the troops led by Captain Supomo. The battle continued to Segara Kembang Village, Sindang Country, Agung Country and Ogan Ulu then returned to Tanjung Karang, Lampung.

At the end of 1948, around December, 2nd Dutch Military Aggression occurred in Lampung, starting from the arrival of the Dutch Army to Lampung Bay and starting to attack Panjang. As a result of the unbalanced Navy weaponry, so the enemy successfully controlled Teluk Betung Panjang.

The chaotic conditions that occurred at that moment made Abu Bakar Sidiq lose many members of the army. Then, Abu Bakar Sidiq received orders to appear before C. Shohoka gave him the task of operating throughout Lampung and accommodating subordinates from members of the Indonesian Navy who were separated from the leading troops.

Abu Bakar Sidiq's struggle with his troops began by agreeing on a war strategy. The war strategy chosen was the Guerrilla war strategy. By studying the situation, the location of the war, making traps, and attacking from several sides.

On January 3rd, 1949 in Gedong Pakuon, South Lampung. Abu Bakar Sidiq, with Sergeant Anuar and Sergeant Adhar, began to research the situation and scout the location of the war. The struggle continued to the Gedong Air Kemiling with the same strategy Abu Bakar Sidiq and his troops managed to make the enemy retreat and get the spoils of war in the form of 5 krabin weapons, three steguns, and one parabellum and bullets.

During the battles at Gedong Air Kemiling, Abu Bakar Sidiq and the guard soldiers reported that there were four TNI personnel who wanted to meet with Abu Bakar Sidiq, namely Sergeant Major M. Yasin, Sergeant Major M. Ilyas, Private I Adenim Umar, and Private I Ilyas who expressed their wish to join forces with Abu Bakar Sidiq.

With the addition of four members from the TNI, there was a change in the attack squad, namely:

- Abu Bakar Sidiq as Commander of troops.

- Commander of Section I Brigade 1 Sergeant Major Adhar leads 30 people

- Commander of Section I Brigade 1 Sergeant Major Anuar leads 30 people

- Commander of Section I Brigade 1 Sergeant Major M. Yasin leads 30 people

- Commander of Section I Brigade 1 Sergeant Major M. Ilyas leads 30 people

(Abu Bakar Sidiq's records)

After three months, Abu Bakar Sidiq and his troops disrupted the Dutch defenses in the Gedong Air dan Kemiling. The struggle continued towards
Sukadanaham. The battle was carried out vigorously without giving the enemy a chance to fight back.

The struggle continued to the Tataan area, which previously the Dutch had succeeded in occupying Tataan due to unbalanced weapons. In this battle, Abu Bakar Sidiq was assisted by Indonesian National Armed Forces (TNI) troops led by Lieutenant Alimuddin. Many Dutch soldiers died and managed to get two mortar boxes, one tek and roof, and several LIF and Stegun carbine bullets. (Abu Bakar Sidiq's note).

In the middle of May, Abu Bakar Sidiq and his troops headed to Kampung Bumi Batu and continued to Simpang Bekri to help defend the highway and help Supomo's men in Wates. In this battle, he managed to get several tens of grenades, two steguns, and one carbine.

\section{The Role of Abu Bakar Sidiq in Maintaining the Residency of Lampung}

Dutch Aggression II boosted by the Dutch resulted in the Central Government of Lampung (the residency of Lampung) moving to Bukit Kemuning, North Lampung because it was a part of the Lampung area that had not still succeeded to be controlled by the Dutch. This made the enemy's movement would go to Bukit Kemuning because this North Lampung area was the only area that was not attacked by the Dutch army.

The situation of Kotabumi in North Lampung has successfully controlled by the enemy's troops that were led by Lieutenant Van Hutten at the time. Abu Bakar Sidiq and his troops had waited the enemy fell into the trap that had been prepared by them and at eight in the morning, a reconnaissance army came to report that the Dutch troops had seen from a distance, then, Abu Bakar Sidiq's troops had been ready to attack immediately.

When the enemy fell into the trap of Landmine, grenades were exploded and started to fire from all sides to push the enemy back. Then, Abu Bakar Sidiq contacted Battalion Commander M. Nurdin to let the troops joined with him. After that, the envoy of $\mathrm{M}$. Nurdin ordered Abu Bakar Sidiq and his troops moved to Banjar Ratu to oversee the roads, railroads while the troops of Lieutenant II Sai Sohar occupied the roads to keep the movement of the Dutch troops became slow from entering Kotabumi.

Abu Bakar Sidiq ordered Sergeant Major Ilyas to review the location and look for strategic places to set traps, attack, and hide at the time. Abu Bakar Sidiq's troops continued to move trying to block the Dutch army from entering North Lampung further, especially in Bukit Kemuning, which was the residence of Lampung at the time.

Abu Bakar Sidiq moved to Napal Belah and asked the head of the village to provide a safe hiding place for the troops in Napal Belah and Kebon Dalam. Brigades 3 and 4, namely Sergeant Major M. Yasin and Sergeant Major M. Ilyas were ordered by Abu Bakar Sidiq to 
occupy Cempaka Village and operate towards Kotabumi. Brigade 2 under the command of Sergeant Anuar occupied Ogan Lima Village and operated to Lepang and its surroundings. Meanwhile, Brigade 1 under the command of Sergeant Major Adhar prepared to assist the front troops if it was needed.

After completing the division of tasks, Sergeant Major Adhar was ordered by Abu Bakar Sidiq to meet the head of the villages in Bukit Kemuning to collect all the Karabyn, Dubbullop, and Locok weapons in their respective villages that would be used by the owners themselves when registered as paramilitary troops.

After registering weapons and youths for the paramilitary troops, it was followed by a quick military provision and there were 350 paramilitary members that we left in two places, namely: Ulak Rengas and Tanjung Raja Village.

Finally, Kotabumi was completely occupied by the Dutch army. When Kotabumi was successfully occupied, Abu Bakar Sidiq and other troops made a defense strategy, namely:

- The panther troops in Cempaka operated in Kotabumi

- The black bear troops by Sergeant Anuar in Talang Lepang Dalam

- Hizbuallah troops in Talang Sabuk

- The troops of Sergeant Major M. Yasin from black bears who were staffed at Talang Bunglai and hidden posts in Way Kunang

- The troops of Sergeant Major Ilyas from black bears at Talang 40, operated to assist Lieutenant II Mustofa if it was needed.

- The troops of Sergeant Major Adhar with a strength of 2 sections, were staffed in Ogan Lima and operated to assist other troops if it was needed.

- Lieutenant Mustofa's troops are based in Pekurun

- The troops of Lieutenant II Sastro Sumedi and Lieutenant II Johansyah, staffed in Tanjungraja 45 members of Black bear troops from the navy led by Marine Lieutenant Abu Bakar Sidiq

- Sergeant Ishak RK Putera troops, staffed in Cahaya Negeri

The struggle to confront the Dutch army continued to be strengthened, especially around Ogan Lima and Napal Belah, which were located close to Kotabumi and Bukit Kemuning. Doing reconnaissance, setting traps, and shooting targets were continuously carried out so that the enemy could not move forward to other areas or even enter Bukit Kemuning.
According to the instruction of the commander of ALRI related to holding a cease-fire between the Dutch and the Republic of Indonesia, a commission was formed, namely the Local Joint Committee to regulate the implementation of the cease-fire in the legal area of the residency of Lampung in August 1949. It was represented by Captain C. Shohoka from the ALRI's side. Since the cease-fire was held, the ALRI troops at Military Base IA Lampung began to consolidate the personnel field by regrouping members who had been dispersed and followed by recognition of sovereignty from the Dutch side.

On December 27, 1949, a ceremony was held with the raising of the Red and White flag and the lowering of the Dutch flag at the PJKA Kotabumi field. This ceremony was symbolic of the handover of the Lampung area from the Dutch.

\section{DISCUSSION}

The Indonesian nation has gone through a long historical journey to escape from the power of foreign nations with difficult struggles. The proclamation of independence on August 17, 1945, was a very important moment or event for the Indonesian nation. Although Indonesia has succeeded in proclaiming independence, the struggle was not over yet.

The Dutch tried to regain control of Indonesia by all means. The negotiations proposed by the Dutch were actually for their own sake until the Dutch Military Aggression I and Dutch Aggression II had an impact on the Lampung area.

The appearance of the Dutch Army during the Second Military Aggression in the last months of 1948 to the beginning of the year at Betung Bay of Panjang surprised the ALRI Military Base IA Lampung at that time so that the Dutch Army could occupy it.

Abu Bakar Sidiq was one of the regional fighters who was willing to sacrifice his body and soul to defend Lampung so that it remained as a part of an independent area of Indonesia. Abu Bakar Sidiq who was originally part of the police, moved to the Navy Base IA Lampung persistently and continued to fight together with his troops and the weapons they had, and arranged war strategies.

The struggle journey of Abu Bakar Sidiq was originally started while he was involved to help Palembang to confront the enemy armies who wanted to enter the Palembang area. Then, it continued with the long struggle almost in all areas in Lampung, namely, Gedong Pakuon South Lampung, Gedong AirKemiling, Sukadanaham, Way Lima, and North Lampung.

Even though the forces were not balanced as well as the weapons, they did not give up. When the situation in Lampung was getting more pressing, it resulted in the residency of Lampung moving from Talang PadangWay Tenong and ending up in Bukit Kemuning, North 
Lampung. Abu Bakar Sidiq immediately arranged a defense strategy and divided tasks into several troops.

Moreover, the Dutch succeeded in occupying Kotabumi, Abu Bakar Sidiq immediately consolidated with other troops, namely Hizbullah and Sergeant II Mustofa troops to form and divide troops into several groups with different operating bases.

Not only that, but Abu Bakar Sidiq also immediately ordered the heads of the village of Bukit Kemuning to collect their weapons and recruit youth becoming members of the People's paramilitary, who would be armed and taught about military training.

The efforts made by Abu Bakar Sidiq and his troops turned out to be successful in making the Dutch difficult to enter around the area of Bukit Kemuning, which was located as the residency of Lampung.

Finally, a red and white flag-raising ceremony was held at the PJKA Kotabumi field on December 27, 1949, as a symbol of the handover of the Lampung area that meant Lampung remained as a part of the Independent Republic of Indonesia.

\section{CONCLUSION}

Abu Bakar Sidiq is a fighter/ hero from the Lampung region who has a significant contribution in maintaining Lampung so that it remains as a part of the Independent Republic of Indonesia.

His experiences started from the TKR commander in the sub-district of Bukit Kemuning, Commander of the Special Police Force, Head of Lampung Regional
Police Equipment, and he joined the ALRI in the Lampung IA Base at the end, these have made Abu Bakar Sidiq a fighter who has a very high nationalist spirit.

Abu Bakar Sidiq's struggle was not only spread throughout the Lampung area but his struggle also reached Palembang. Abu Bakar Sidiq and his troops played a significant role in defending Lampung, especially, North Lampung, which was the last place for the residency of Lampung at the time.

\section{REFERENCES}

[1] D. S. Suraputra. Revolusi Indonesia dan Hukum Internasional. UI Press: Jakarta, 1991.

[2] MC. Ricklefs. Sejarah Indonesia Modern 1200-2004. Jakarta: Serambi. 2008.

[3] J. Pour. Doorstoot naar djokja: Pertikaian pemimpin sipilmiliter. Penerbit Buku Kompas. 2009.

[4] S. Soekanto. Sosiologi Suatu Pengantar Edisi Baru. Jakarta : Rajawali Pers. 2009.

[5] B. J. Cohen. Metode Penelitian Deskriptif. Jakarta: Gramedia. 1992.

[6] W. J. S. Poerwadarminta. Kamus Umum Bahasa Indonesia. Jakarta: Balai Pustaka. 1995

[7] A. Imron, H. Susanto, T. Sukiji, Wakidi, and H. Sayuti. Sejarah Pembentukan Provinsi Lampung. Bandar Lampung: Badan Penelitian dan Pengembang Daerah Propinsi Lampung. 2001.

[8] N. Notosusanto. Hakekat Sejarah dan Asas-azas Metode Sejarah.Mega Bookstore. 1964. 